\title{
Air quality in the City of La Paz, Mexico: emissions inventory and air pollutants
}

\author{
A. Ivanova ${ }^{1}$, A. Bermudez ${ }^{2}$, A. Martinez ${ }^{1} \&$ A. Montaño ${ }^{1}$ \\ ${ }^{1}$ Department of Economics, \\ Universidad Autonoma de Baja California Sur, Mexico \\ ${ }^{2}$ Department of Fisheries, \\ Universidad Autonoma de Baja California Sur, Mexico
}

\begin{abstract}
In the City of La Paz, Mexico, there is growing concern amongst the local population regarding a decline in the local air quality. This paper presents the main results of an air pollutants emissions inventory by source category recently completed as a first step to assess the local air quality in La Paz. The reference year for the inventory is 2013 and includes the emission trends for six major air pollutants, and the analyses of four emission source categories. The pollutants included in the inventory are sulphur oxides (SOx), nitrogen oxides (NOx), respirable suspended particulates (RSP or PM10), fine suspended particulates (FSP or PM2.5), volatile organic compounds (VOC), and carbon monoxide (CO). The inventory considers point, area, mobile on-road and natural sources.

The conclusions point out electricity generation and the exaggerated number of cars per capita as the main emissions' sources. Some recommendations are presented for the local authorities such as an Air Quality and Emissions Reduction Plan up to 2025: e.g. imposition of statutory emission caps on power plants, implementation of renewable energies and mandatory annual roadworthiness and exhaust pipe emissions tests for on-road vehicles.

Keywords: emissions inventory, air pollutants, La Paz, Mexico.
\end{abstract}

\section{Introduction}

La Paz city is the capital of BCS and is the seat of the municipality with the same name. To the City of La Paz and surrounding areas the coasts of the Sea of Cortez are of great importance for the development, given that the activities that support 
the local people include maritime trade, fishing, tourism and services. However, agricultural activities are also developed in the valleys [1]. The city concentrates most of the government agencies, educational institutions and health centers in the state of Baja California Sur.

The rapid population growth has led to a change in the city environment due primarily to the generation of waste, growth of the vehicle pool and deforestation $[2,3]$. Likewise, poor urban planning has caused several pollution problems and increased emissions.

The population of the City of La Paz has grown rapidly in the last years, which is denoted by community movement migrations. The National Council of Population (CONAPO) estimates that the City of La Paz has a population of 233,559 inhabitants in 2013 [4]. Population growth accelerated the challenge to achieve proper planning of urban growth (Figure 1) and enhance the sustainable development. The lack of proper planning of urban development has caused various problems including increased emissions of pollutants that affect air quality.

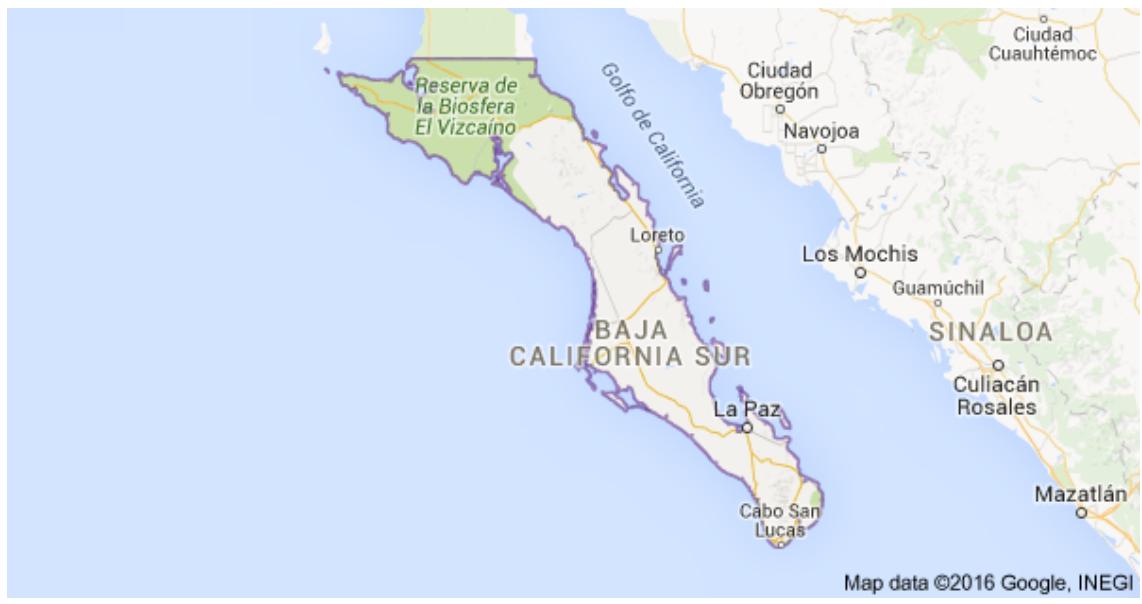

Figure 1: Location of the City of La Paz, Mexico.

Simultaneously, other sources of emissions are the major electricity generation plants of the Federal Electricity Commission (CFE) located locally: Central Internal Combustion (CCI) Baja California Sur and Central Termoelectrica (CT) Punta Prieta. The amount of electricity produced in these plants is considerably higher than the needs of $\mathrm{La} \mathrm{Paz}$, and the excess generated is intended to supply the electricity needs of other parts of the state. In turn, this is compounded by the type of inputs. The main fuel used in electricity generation in $\mathrm{La} \mathrm{Paz}$ and the state in general is fuel oil with high sulfur content. 


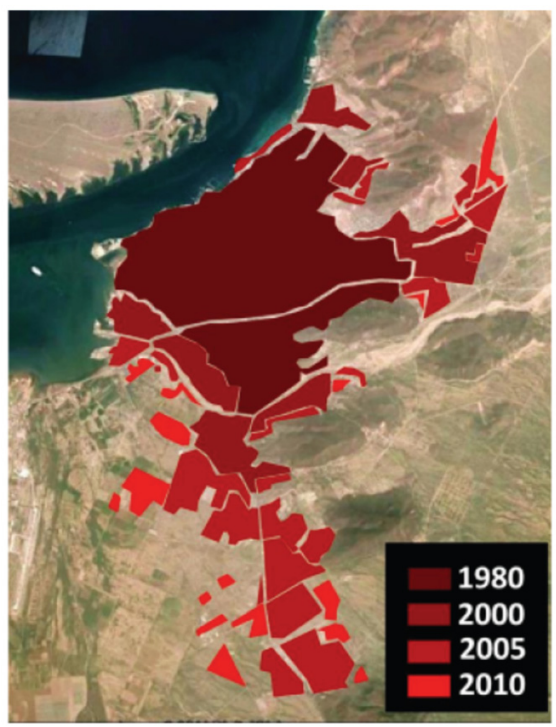

Figure 2: $\quad$ Growth of urban footprint of La Paz (source [3]).

Thus, the local air contains mixture of particles and chemicals that could have serious implications on:

- The health of city inhabitants with private and social costs associated [5],

- The health of nearby ecosystems, and

- The competitiveness of economic activities of La Paz (e.g., tourism).

The emissions inventory and the determination and valuation of externalities may serve as inputs in the development of an Air Quality and Emissions Reduction Plan up to 2025.

\section{Objective of the study and methodology}

\subsection{Objective}

The implementation of actions, procedures and programs to maintain a minimum standard of quality of the air requires knowledge of the emissions in terms of type, size, composition and origin. For this, the objective of this study is to develop an inventory of emissions of nitrogen oxides (NOx), sulfur oxides (SOx), volatile organic compounds (VOCs), carbon monoxide (CO), particulate matter less than or equal aerodynamic diameter 2.5 microns (PM2.5), and particulate matter less than or equal to 10 micrometers (PM10) for the city of La Paz, Baja California Sur, to identify and characterize emission sources and quantify the magnitude of these. 


\subsection{Area of the inventory}

The boundaries of the study area of this Emission Inventory are shown in the map in Figure 3. Surrounding areas were included because of their influence on economic and social life of the city, as are particularly relevant in sectors such as transport and farming and fishing activities. The area of study and localities included were defined in consultation with officials from the City Council.

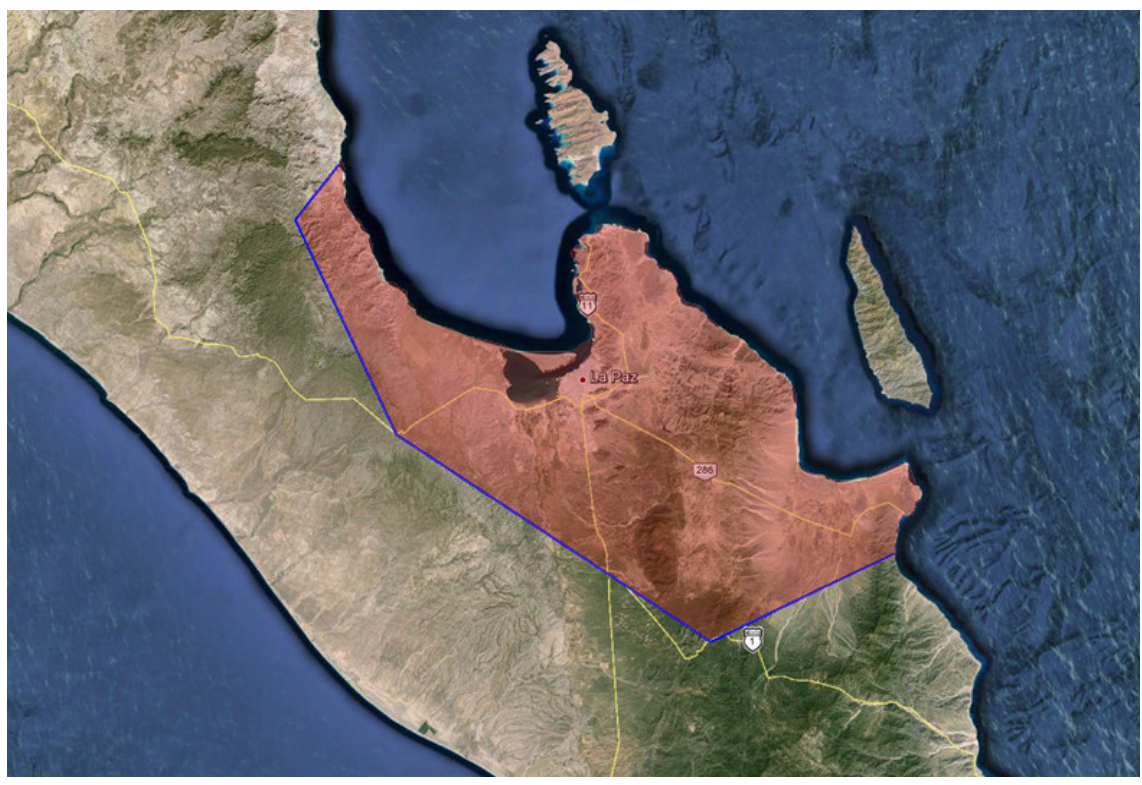

Figure 3: Study area: La Paz and surrounding areas (source [1]).

\subsection{Base year}

In the preparation of the inventory it was selected 2013 as the base year. The reason for this was the availability of information for the different sources of emission of pollutants studied. Particularly due to the change of format of the certificates of annual operation (COA) for reporting years 2014 onwards, the most recent available COAs corresponding to electricity generation plants at the time of this work were those of 2013.

\subsection{Methodology for estimating emissions}

In general, the methodology for estimating emissions is the use of an emission factor, which relates the released amount of a certain contaminant with an activity related to the release of such contaminant. The emission factor is given by the ratio of the amount of mass of the pollutant in question which is released into the atmosphere divided by a unit of measurement of the activity that generates it. Such measurement unit can be, for example, the mass or volume of fuel used or the 
duration of operation process. Also mitigate mechanisms exist emission of pollutant inventoried, this is taken into consideration also. Thus, the general equation for estimating emissions is:

$$
E_{i}=F E_{i} * A *\left(1-\frac{E R_{i}}{100}\right)
$$

where

$\mathrm{E}$ is the amount of the pollutant emitted;

FEi is the emission factor of pollutant I;

A is the activity data associated with the release of the pollutant I;

ER is efficiency (percentage) reduction of the emission of the pollutant $i$.

It should be mentioned that, methodologically, the development of this work was based on various documents and resources such as the Guide for Development and Uses of Emissions Inventory [6], the Methodological Guide for Estimating Emissions from Fixed Sources [7], the Methodological Guide for Estimating Emissions from Vehicles in Mexican Cities [8], Technical Manuals Program Mexico Emissions Inventory [9] as well as some other articles and sources.

\subsection{Energy balance}

The balance sheet [10] resulted in a total energy use in La Paz during 2013 of $25,887 \mathrm{TJ}$, of which electricity generation was the main use as shown in Figure 4. It should be noted that not all electricity generated in La Paz is consumed locally but also serves to supply the consumption of other locations around the state.

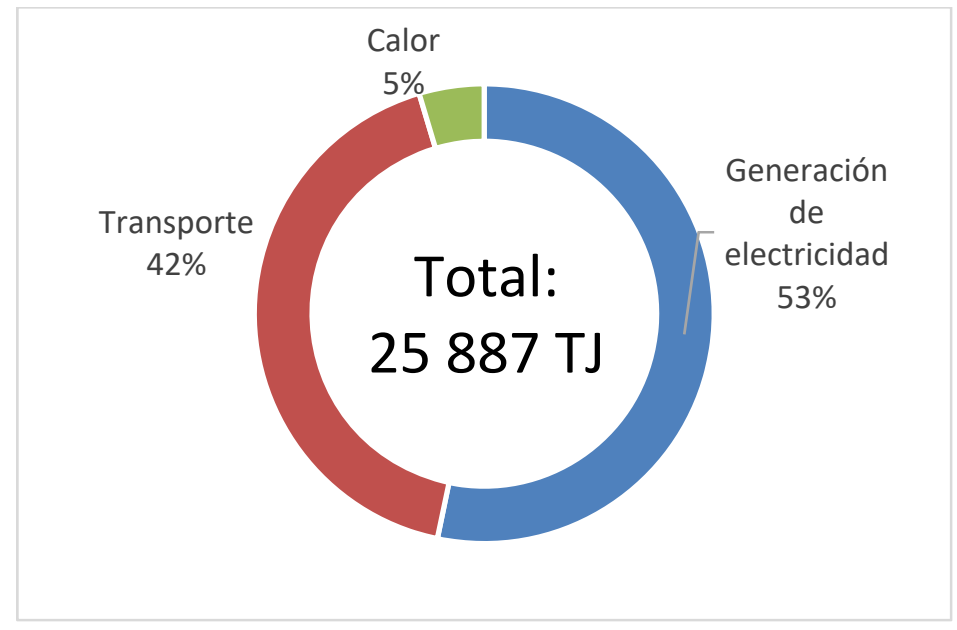

Figure 4: Energy balance sheet for the city of La Paz, 2013 (source: prepared by the authors based on [1]). 


\section{Types of emission sources}

\subsection{Fixed or point sources}

It refers to "any facility established in one place, that is intended to develop operations or industrial processes, commercial, services or activities that generate or may generate emissions into the atmosphere" [11] including:

- The chemical, oil and petrochemical, paints and inks, automotive, pulp and paper, metal, glass, electric power generation, asbestos, cement and lime and hazardous waste treatment.

- All establishments, projects (industrial, commercial or service) activities administered by federal government agencies.

- Sources affecting the ecological balance of an adjacent state or country.

\subsection{Mobile sources}

These consist of motor vehicles with a displacement within the study area, such as private cars, trucks, motorcycles and buses for public or private use. Emissions from motor vehicles are made up of various pollutants and processes:

- Exhaustion emissions.

- Hot humid emissions.

- Evaporative emissions.

- Diurnal emissions.

- Evaporative emissions at rest.

- Evaporative emissions from refueling.

\subsection{Area sources}

It refers to sources, establishments or activities presented scattered but in great amount, and individually do not emit into the atmosphere large quantities of chemicals, gases or particles, but in aggregate can generate significant emissions.

\subsection{Natural sources}

All those sources that emit pollutants of no direct anthropogenic origin are considered natural sources. These can be defined as biogenic or geogenic. The former includes emissions of volatile organic compounds (VOC) emissions generated by crops or soil. The latter are of geological origin, such as springs, volcanoes or geysers.

\section{Total emissions}

Having estimated emissions of criteria pollutants for fixed, mobile, area and natural sources, we proceeded to add the data of each source. The results of this are shown schematically in the Sankey diagram (see Figure 5). As shown, the higher emissions coming from stationary sources, which are the main 
generators of emissions of oxides of sulfur and nitrogen. The particles are also mainly emitted by fixed sources.

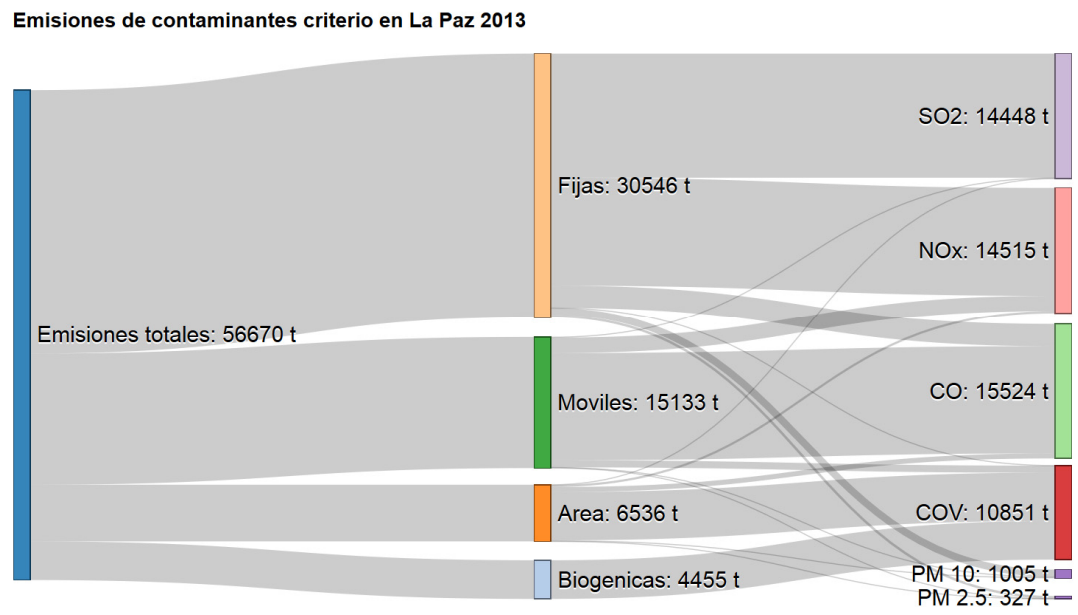

Figure 5: Sankey diagram of emissions in La Paz, 2013 (source [1]).

Second in total emissions corresponds to mobile sources, the main pollutant emitted is carbon monoxide. For natural sources area and the main pollutions emitted are volatile organic compounds. In addition,, to get a better idea of the contribution of each pollutant in each source (see Figure 6 and Table 1).

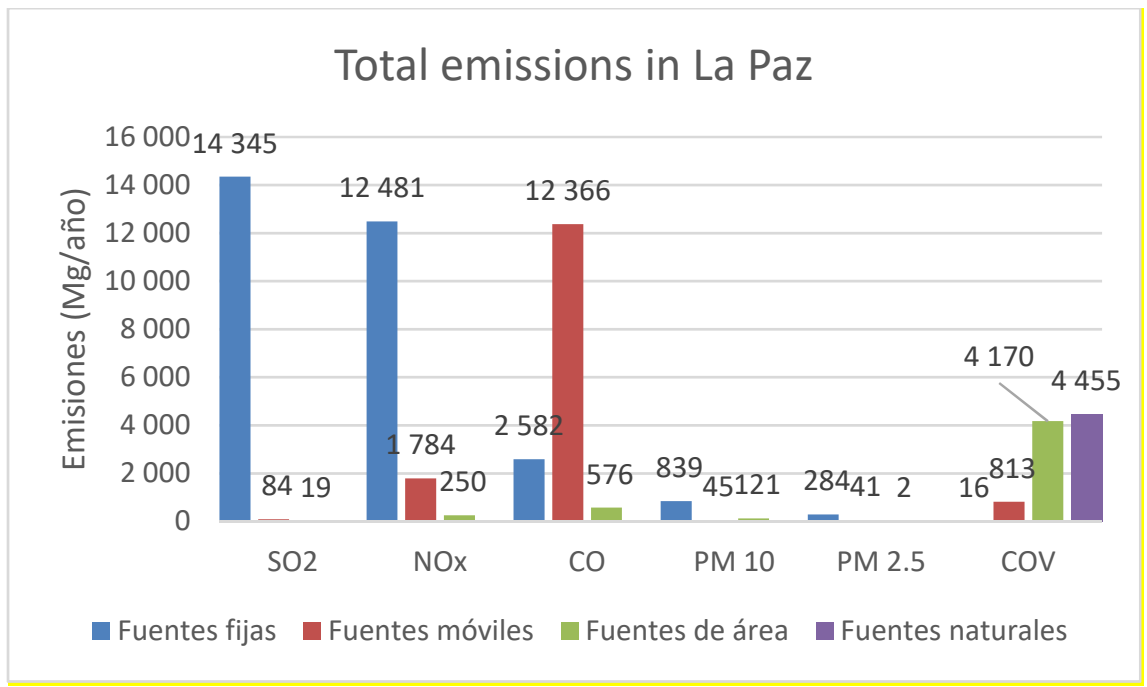

Figure 6: Emissions by source and by pollutant in La Paz, 2013. 
It is worth mentioning the rapid growth of vehicles in the city of La Paz (Figure 7). The diagnosis of mobility developed within the Plan for Sustainable Urban Mobility (PIMUS) of La Paz states (including an estimate of illegal vehicles without registration), that the rate of motorization of the city could even reach 1.27 vehicles per capita, i.e. more cars than people if considering unregistered vehicles.

Table 1: $\quad$ Emissions by source and by pollutant in La Paz, 2013.

\begin{tabular}{|c|c|c|c|c|c|c|c|}
\hline \multirow{2}{*}{$\begin{array}{c}\text { Type of } \\
\text { source }\end{array}$} & \multicolumn{7}{|c|}{ Emissions (Mg/year) } \\
\cline { 2 - 8 } & $\mathbf{S O}_{\mathbf{2}}$ & NOx & $\mathbf{C O}$ & PM 10 & PM 2.5 & COV & TOTAL \\
\hline Fixed & 14345 & 12481 & 2582 & 839 & 284 & 16 & $\mathbf{3 0 5 4 6}$ \\
\hline Mobile & 84 & 1784 & 12366 & 45 & 41 & 813 & $\mathbf{1 5 1 3 3}$ \\
\hline Area & 19 & 250 & 576 & 121 & 2 & 5567 & $\mathbf{6 5 3 6}$ \\
\hline Natural & & & & & & 4455 & $\mathbf{4 4 5 5}$ \\
\hline TOTAL & $\mathbf{1 4 4 4 8}$ & $\mathbf{1 4 5 1 5}$ & $\mathbf{1 5 5 2 4}$ & $\mathbf{1 0 0 5}$ & $\mathbf{3 2 7}$ & $\mathbf{1 0 ~ 8 5 1}$ & $\mathbf{5 6 ~ 6 7 0}$ \\
\hline
\end{tabular}
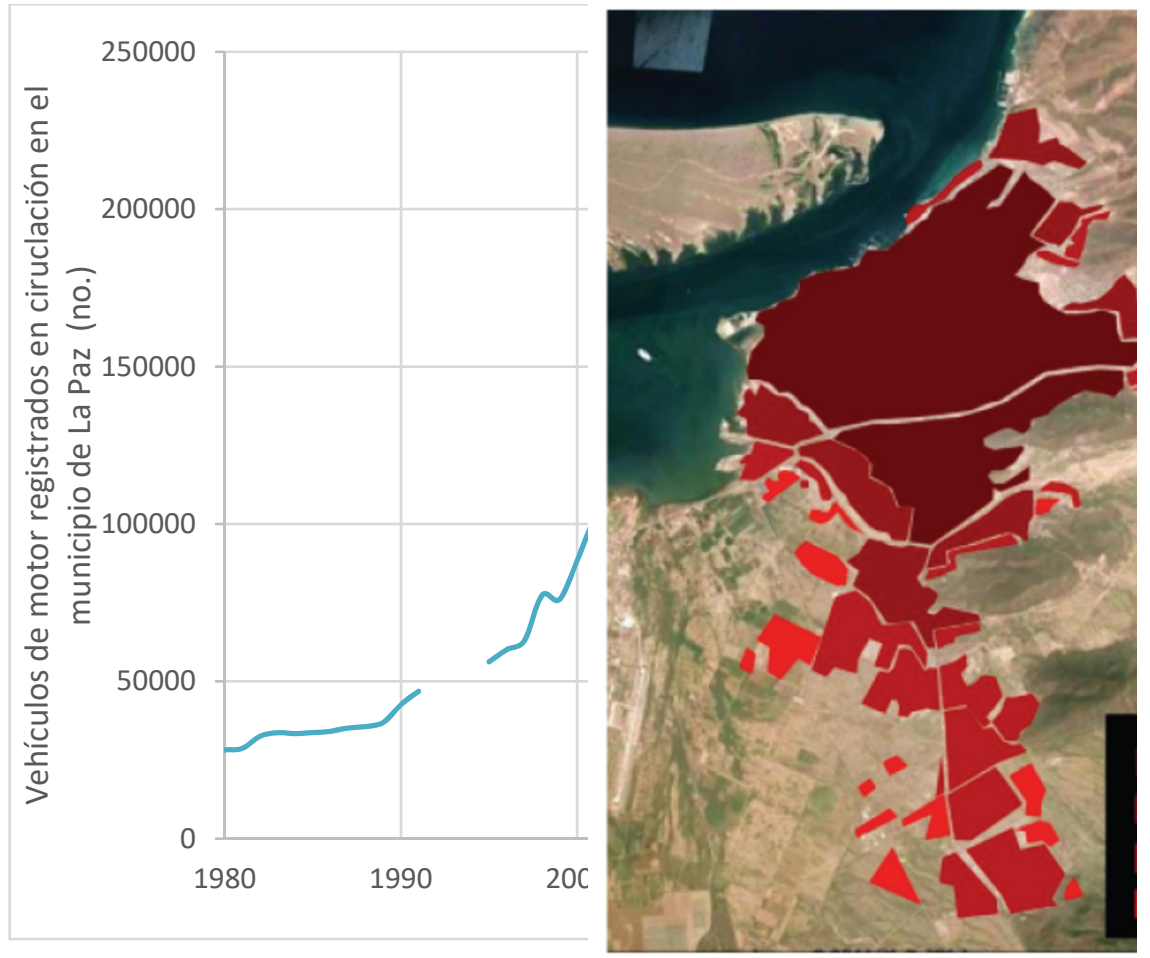

Figure 7: Growth of municipal vehicle fleet and the surface of the city of La Paz. (Source: left and right prepared by the authors based on the data of [12] and [13]). 


\section{Concluding remarks}

Electricity generation and the exaggerated number of cars per capita are the main emission sources in La Paz, Mexico. The main pollutants are sulfur oxides $\left(\mathrm{SO}_{2}\right)$, nitrogen oxides (NOx) and carbon monoxide (CO). Some recommendations a for the local authorities are to deliver an Air Quality and Emissions Reduction Plan up to 2025: e.g. imposition of statutory emission caps on power plants, implementation of renewable energies and mandatory annual roadworthiness and exhaust pipe emissions tests for on-road vehicles. The State Government already has begun the procedure to obtain support from Federal Government to establish measures that enhance the air quality and to acquire proper instruments to perform continually measurement of the air quality.

\section{References}

[1] Ivanova Boncheva, A, Bermúdez Contreras, A, de la Peña, A, de la Toba, D, Encarnación, E, Geiger, A, Gómez, I, Graciano, JC, Juárez, E, Kachok, R, López, C, Martínez, M, Martínez, V, Moreno, G, Petatán, D, Polanco, G, Ramírez, E, Rangel, E, Reyes, H, Rivera, J \& Wurl, J, Plan de Acción ante el Cambio Climático para La Paz y sus Áreas Colindantes. 2013

[2] Ivanova, A. \& A. Gamez Programa Estatal de Acción ante el Cambio Climático, PEACC, 2012. Available at: http://spyde.bcs.gob.mx/cgds/files/ proyectos/PEACC/foros/Presentacion_Informativa_Foros_PEACC.pdf $(05 / 03 / 2016)$

[3] CONAPO, Baja California Sur: Proyecciones de población de localidades seleccionadas 2010-2030, 2015a. Available at http://www.conapo.gob.mx /es/CONAPO/Proyecciones_Datos (20/02/2015)

[4] CONAPO, Proyección de la población de los municipios a mitad de año por sexo y grupos de edad, 2010-2030 - Baja California Sur, CONAPO, 2015b, Available at: http://www.conapo.gob.mx/es/CONAPO/ Proyecciones_Datos, (16/02/2016)

[5] Samet, JM, Dominici, F, Zeger, SL, Schwartz, J \& Dockery, DW, "The National Morbidity, Mortality, and Air Pollution Study. Part I: Methods and methodologic issues.", Research report (Health Effects Institute), 2000, $\mathrm{n}^{\circ}$ 94, pp. 5-14; discussion 75-84

[6] SEMARNAT, INE \& WGA, Guía de elaboración y uso de inventarios de emisiones, 2005. Available at: http://www2.inecc.gob.mx/publicaciones /consultaPublicacion.html?id_pub=457, (14/03/2016)

[7] SEMARNAT \& INECC, Guía Metodológica para la Estimación de Emisiones de Fuentes Fijas, 2013, Available at: http://www2.inecc.gob.mx/publicaciones/download/696.pdf (14/03/2015)

[8] SEMARNAT \& INE, Guía metodológica para la estimación de emisiones vehiculares en ciudades mexicanas, 2009. Available at: http://www2.inecc.gob.mx/publicaciones/consultaPublicacion.html?id $(16 / 03 / 2016)$ 
[9] INECC. Technical Manuals Program Mexico Emissions Inventory, 2014. Available at: http://www.inecc.gob.mx/Calaire-information-basic/551Calaire-inv-emission, (18/04/2016)

[10] SENER, Balance Nacional de Energía 2013, Secretaría de Energía, 2014. Available at: www.sener.gob.mx/res/PE_y_DT/pub/2013/Balance 2013.pdf (20/04/2016)

[11] RLEEGEPAMPCCA, "Reglamento de la Ley General de Equilibrio Ecológico y Protección al Ambiente en Materia de Prevención y Control de la Contaminación a la Atmósfera, con reformas del 31-10-2014", 2014, Diario Oficial de la Federación 31-10-2014

[12] INEGI, Motocicletas registradas en circulación, 2016a, Available at: http://www3.inegi.org.mx/sistemas/biinegi/ (24/04/2016)

[13] INEGI, Vehículos de motor registrados en circulación (excluye motocicletas), 2016b, Available at http://www3.inegi.org.mx/ sistemas/biinegi/ (18/05/2016) 